\title{
Proposal of ATCC 25396 as the Neotype Strain of Microcyclus aquaticus Ørskov 1928
}

\author{
JOHN M. LARKIN AND RENEE BORRALL \\ Department of Microbiology, Louisiana State University, Baton Rouge, Louisiana 70803
}

Ørskov's original isolate of Microcyclus aquaticus has been lost. ATCC 25396 is similar to the original isolate and is proposed as the neotype strain of $M$. aquaticus.

In 1928 Ørskov isolated a single strain of an organism which he considered to represent a new genus and which he named Microcyclus aquaticus (7). No type strain was designated, but his isolate must be considered as the type by monotypy (Rule 18c of the Bacteriological Code [5]). A culture of this strain was deposited with the National Collection of Type Cultures (NCTC) in London, but Ørskov stated that it was subsequently lost, as were his own cultures (8). Later, he reported finding additional strains (8), and he stated that the "description published previously applies today as regards the new strains." Consequently, Ørskov prepared the description of the genus as it appeared in the seventh edition of Bergey's Manual (9).

In 1959 Ørskov deposited a culture of one of his new isolates with the Biologický Ustav Ceskoslovenská Akademic Ved (BUCSAV), and it was given the accession number 410. BUCSAV was merged with the Czechoslovak Collection of Microorganisms (CCM) in 1975, and the organism was given the accession number 1786 in the CCM collection. In 1961 this strain was sent to the National Collection of Industrial Bacteria (NCIB) and was given the accession number 9271. Therefore, BUCSAV $410=$ CCM $1786=$ NCIB 9271.

In 1961 the Deutsche Sammlung von Mikroorganismen (DSM) received a strain of $M$. aquaticus without additional comment from $\emptyset \mathrm{r}$ skov (D. Claus, personal communication), and it was given the accession number 101. The DSM strain was subsequently sent to $H$. D. Raj, who deposited it in the American Type Culture Collection (ATCC), where it received the accession number 25396. Therefore, DSM $101=$ Raj Mc-2 = ATCC 25396. Because Ørskov had several strains of $M$. aquaticus in his possession, there is no way of determining if the strain he deposited with BUCSAV and that he deposited with DSM were the same. Consequently, there is some question as to whether or not the strains in the above-named culture collections are identical. Moreover, the catalogs of those culture collections all indicate that they carry the "Ørskov" strain, and at least two of them (ATCC, DSM) indicate that it is the type strain. Bergey's Manual (12) also indicates that ATCC 25396 is the type strain. However, it is clear that none of the strains in any of the culture collections is a subculture of Ørskov's original isolate. To avoid additional confusion, it would be beneficial to designate a neotype strain of $M$. aquaticus.

Ørskov's original paper (7) contained an extensive description of the organism's morphology, life cycle, and culture characteristics. There was no indole, hemolysin, or gelatinase production, no growth at $37^{\circ} \mathrm{C}$, and no motility. The cell size averaged about $1 \mu \mathrm{m}$ in diameter and 2 to $3 \mu \mathrm{m}$ in length. Out of 13 carbohydrates, only arabinose was fermented, and then only after 6 weeks. With his second isolates (8) he added the presence of capsules and the delayed fermentation of xylose to the description.

Ørskov did not reveal what kind of basal medium he used for the carbohydrate studies. In 1970 , Raj (10) studied acid production from 22 carbohydrates by $M$. aquaticus ATCC 25396. He compared results from three basal media and concluded that Ørskov must have used a medium such as purple broth base. Acid production in purple broth occurred, but slowly, from arabinose and xylose only, whereas acid production in Hugh-Leifson medium occurred with a variety of carbohydrates, but only oxidatively. He concluded that ATCC 25396 agreed closely with the original description of $M$. aquaticus.

Since ATCC 25396 is the only strain of $M$. aquaticus extensively studied and described (1$4,6,10,11$ ), and since it agrees closely with Ørskov's original description (7) by Ørskov's own later account (8), in the interest of preventing additional confusion we propose that ATCC 25396 be designated the neotype strain of Microcyclus aquaticus.

\section{ACKNOWLEDGMENTS}

We thank V. Musilek of the Czechoslovak Academy of Science and Margaret Hendrie of the National Collection of 
Industrial Bacteria for answering our inquiries concerning the origin of the strains in their collection. Special thanks must be extended to D. Claus of the Deutsche Sammlung von Mikroorganismen for supplying advice and reprints.

A portion of the work referenced in the article was supported in part by National Science Foundation grant DEB. 78-01326.

\section{REPRINT REQUESTS}

Address reprint requests to: Dr. John M. Larkin, Department of Microbiology, Louisiana State University, Baton Rouge, LA 70803.

\section{LITERATURE CITED}

1. Claus, D., J. E. Bergendahl, and M. Mandel. 1968. DNA base composition of Microcyclus species and organisms of similar morphology. Arch. Mikrobiol. 63: 26-28.

2. Konopka, A. E., J. C. Lara, and J. T. Staley. 1977. Isolation and characterization of gas vesicles from $\mathrm{Mi}$ crocyclus aquaticus. Arch. Microbiol. 112: 133-140.

3. Konopka, A. E., R. L. Moore, and J. T. Staley. 1976. Taxonomy of Microcyclus and other nonmotile, ringforming bacteria. Int. J. Syst. Bacteriol. 26:505-510.

4. Kottel, R. H., and H. D. Raj. 1973. Pathways of carbohydrate metabolism in Microcyclus species. J. Bacteriol. 113:341-349.
5. Lapage, S. P., P. H. A. Sneath, E. F. Lessel, V. B. D. Skerman, H. P. R. Seeliger, and W. A. Clark (ed.). 1975. International code of nomenclature of bacteria, 1976 revision. American Society for Microbiology, Washington, D.C.

6. Larkin, J. M., P. M. Williams, and R. Taylor. 1977. Taxonomy of the genus Microcyclus Ørskov 1928: reintroduction and emendation of the genus Spirosoma Migula 1894 and proposal of a new genus, Flectobacillus. Int. J. Syst. Bacteriol. 27:147-156.

7. Ørskov, J. 1928. Beschreibung eines neuen Mikroben, Microcyclus aquaticus, mit eigentümlicher Morphologie. Zentralbl. Bakteriol. Parasitenkd. Infektionskr. Hyg. Abt. 1 Orig. 107:180-184.

8. Ørskov, J. 1953. Microcyclus. Riassunti d. communicazioni. VI Congr. Int. Microbiol. Roma 1:24-25.

9. Orskov, J. 1957. Genus Microcyclus, p. 253. In R. S. Breed, E. G. D. Murray, and N. R. Smith (ed.), Bergey's manual of determinative bacteriology, 7th ed. The Williams \& Wilkins Co., Baltimore.

10. Raj, H. D. 1970. A new species-Microcyclus flavus. Int. J. Syst. Bacteriol. 20:61-81.

11. Raj, H. D. 1976. A new species: Microcyclus marinus. Int. J. Syst. Bacteriol. 26:528-544.

12. Staley, J. T. 1974. Genus Microcyclus, p. 214. In R. E. Buchanan and N. E. Gibbons (ed.), Bergey's manual of determinative bacteriology, 8th ed. The Williams \& Wilkins Co., Baltimore. 